DOI https://doi.org/10.30525/978-9934-26-173-2-35

\title{
МЕТОДИЧНА КОМПЕТЕНТНІСТЬ МАЙБУТНЬОГО УЧИТЕЛЯ ПОЧАТКОВИХ КЛАСІВ: НОРМАТИВНО-ПРАВОВИЙ АСПЕКТ
}

\author{
Щур B. А. \\ аспірант \\ Комунальний заклад вищчої освіти
}

«Одеська академія неперервної освіти Одеської обласної ради»

м. Одеса, Україна

На сьогодні, світовою спільнотою визначена приорітетність освіти, яка не лише впливає на формування окремої особистості, але й на розвиток суспільтва, в цілому. Вітчизняна освіта зазнає масштабних концептуальних змін, відтак, мова йде про модернізацію всієї системи. Такі трансформації відбуваються у контексті загальної глобалізації, швидкої інтеграції України у європейський освітній простір, якісних і часто незворотніх процесів в усіх сферах життя людини.

У Концепції Нової української школи зазначено, що традиційна школа наразі не відповідає розвитку світового суспільства, організація навчання не мотивує школярів, учителі використовують переважно застарілі дидактичні засоби, збільшується цифровий розрив між учителем і учнем тощо [3, с. 4]. Тому перехід сучасної освіти на новий рівень функціонування $є$ необхідним і виправданим кроком. Особливої уваги у цих трансформаціях заслуговує початкова школа як важлива ланка освіти, адже, саме в ній закладаються основи наукового світогляду, розвиваються ключові та предметні компетентності, формується система наскрізних умінь тощо. У законі України «Про повну загальну середню освіту» зазначено, що система загальної середньої освіти функціонує 3 метою забезпечення формування в учнів визначених компетентностей [2].

У контексті переорієнтації та зміни ролі самого вчителя як ключового учасника освітнього процесу з'явилися і нові компетентності педагога НУШ, його модернізовані соціальні ролі (ментор, коуч, новатор, фасилітатор, тьютор), а відтак, це, безумовно, впливає на процес підготовки майбутніх учителів.

Відповідно до Професійного стандарту вчителя мета його професійної діяльності полягає «в організації навчання та виховання учнів під час здобуття ними повної загальної середньої освіти шляхом формування у них ключових компетентностей і світогляду на основі загальнолюдських і національних цінностей, а також розвитку 
інтелектуальних, творчих і фізичних здібностей, необхідних для успішної самореалізацї та впровадження навчання» $[6$, с. 1$]$.

Цілком реалізувати поставлену мету можливо лише за наявності у самого вчителя загальних і професійних компетентностей, необхідних для виконання всіх трудових функцій [6]. Тому перед закладами передфахової вищої освіти стоїть виклик - підготовка майбутніх учителів початкових класів у відповідності до нової парадигми освіти.

3 огляду на актуальність окресленої проблеми, маємо за мету проаналізувати нормативні документи для з'ясування змісту методичної компетентності, якою має володіти майбутній вчитель початкових класів у педагогічному фаховому коледжі.

В Освітній програмі першого рівня освіти «Початкова освіта» (2018 р.) Комунального закладу «Балтський педагогічний фаховий коледж» за освітньо-професійним ступенем «молодший спеціаліст» визначено предметно-методичну компетентність, що розглядається у складі фахових спеціальних компетентностей як перелік здатностей: моделювати зміст навчання відповідно до обов'язкових результатів навчання учнів; формувати та розвивати в учнів ключові компетентності та уміння, спільні для всіх компетенцій; добирати і використовувати сучасні та ефективні методики i технології навчання, виховання i розвитку учнів; розвивати в учнів критичне мислення; здійснювати оцінювання та моніторинг результатів навчання учнів на засадах компетентнісного підходу; формувати в учнів ціннісні ставлення [5].

У Освітньо-професійній програмі «Початкова освіта» 3 однією додатковою спеціалізацією: керівник дитячого художнього хорового (хореографічного) колективу; з правом викладання англійської мови в початкових класах; соціальний педагог; вчитель фізичної культури початкової школи коледжу за освітньо-професійним ступенем «фаховий молодший бакалавр» (2020р.) К3 «Балтський педагогічний фаховий коледж», методична компетентність розглядається у складі спеціальних (фахових, предметних) компетентностей та визначається як «здатність ефективно діяти, розв'язуючи стандартні та проблемні методичні задачі під час навчання учнів освітніх галузей/змістових ліній, визначених Державним стандартом початкової загальної освіти» [4, с. 14] та грунтується на теоретичній i практичній готовності до проведення занять за різними навчальними комплектами, що виявляється у сформованості системи дидактико-методичних знань і умінь із окремих розділів та тем курсу, окремих етапів навчання й досвіду їх застосування та наявності емоційно-ціннісного ставлення до діяльності щодо навчання учнів предмету [4, с. 14$]$. 
Поняття «методична компететність» у цьому ж документі конкретизується через такі складники: нормативний («здатність учителя користуватися нормативними документами та реалізовувати на практиці цілі і завдання навчання предмету/освітньої галузі в початковій школі»); варіативний («здатність учителя працювати за будь-яким навчальнометодичним комплектом, здатність обирати найефективніший навчально-методичний комплект для досягнення цілей i завдань навчання предмета/освітньої галузі в початковій школі, визначених Державним стандартом i навчальною програмою»); спеціальнометодичний («здатність до навчання молодших школярів будь-яким елементам змісту програми»); контрольно-оцінювальний («здатність до реалізації критеріїв оцінювання навчальних досягнень учнів початкової школи; здатність дотримування Державних вимог до рівня загальноосвітньої підготовки учнів початкової школи, визначених у програмі»); проектувально-моделювальний («здатність моделювати та організовувати освітній процес в початковій школі; спроможність учителя обирати необхідні засоби, форми, методи та технології організації навчальної діяльності школярів»); технологічний («здатність упроваджувати сучасні технології, інноваційні підходи, передовий педагогічний досвід до навчання окремих питань певної освітньої галузі/предмету початкової школи») [4, с. 14-16].

Отже, аналізуючи вищезгадані документи, можемо прослідкувати, що саме формулювання змісту методичної компетентності майбутнього вчителя початкових класів у закладі передфахової вищої освіти різне, але його змістове наповнення тотожне і виражається у здатності ефективно організовувати та провадити освітній процес у початковій школі з урахуванням вимог Державного стандарту та на засадах компетентнісного підходу.

У площині нашого досілдження, зауважимо, що у професійному стандарті за професіями «Вчитель початкових класів закладу загальної середньої освіти», «Вчитель закладу загальної середньої освіти», «Вчитель 3 початкової освіти (з дипломом молодшого спеціаліста)» серед професійних компетентностей визначено предметно-методичну компетентність, яка конкретизує трудову функцію «планування і здійснення освітнього процесу» і розкривається через такі професійні компетентності: «здатність моделювати зміст навчання відповідно до обов'язкових результатів навчання»; «здатність формувати і розвивати в учнів ключові компетентності та вміння, спільні для всіх компетентностей»; «здатність здійснювати інтегроване навчання учнів»; «здатність добирати та використовувати сучасні ефективні методики i технології навчання, виховання і розвитку учнів»; «здатність розвивати 
в учнів критичне мислення»; «здатність здійснювати оцінювання та моніторинг результатів навчання учнів на засадах компетентнісного підходу»; «здатність формувати ціннісні ставлення в учнів» [6, с. 11-13].

Отож, спостерігаємо різні погляди до трактування самого терміну «методична компетентність» у нормативно-правових документах. Сутність даного поняття включає орієнтування в нормативних документах і ефективне модулювання їх змісту із врахуванням очікуваних результатів навчання; формування і розвиток ключових компетентностей в учнів; здатність до навчання молодших школярів програмовому змісту; уміння моделювати та організовувати освітній процес шляхом добору ефективних форм, методів, засобів, сучасних методик і технологій; розвиток в учнів навичок критичного мислення та ціннісних ставлень; здатність здійснювати оцінювання на засадах компетентнісного підходу тощо.

У площині нашого досілдження, нами методична компетентність майбутнього вчителя початкових класів у фаховому педагогічному коледжі трактована як складна багатофункціональну систему професійно-педагогічних умінь і особистісних здатностей педагога, що визначають його спроможність до ефективної організації освітнього процесу відповідно до освітніх завдань.

Перспектива подальших досліджень полягає у визначенні структури методичної компетентності майбутнього вчителя початкових класів в умовах передвахового педагогічного коледжу.

\section{Література:}

1. Державний стандарт початкової освіти. URL: https://zakon.rada.gov.ua/laws/show/688-2019-\%D0\%BF\#Text.

2. Закон України «Про повну загальну середню освіту» від 02.10.2021 № 463-IX. URL : https://zakon.rada.gov.ua/laws/show/46320\#Text.

3. Концепція Нової української школи. URL: https:// www.kmu.gov.ua/.../ukrainska-shkola-compressed.pdf.

4. Освітньо-професійна програма «Початкова освіта» за освітньо-професійним ступенем «фаховий молодший бакалавр» КЗ «Балтський педагогічний фаховий коледж». URL: https://wixlabs-pdfdev.appspot.com/assets/pdfjs/web/viewer.

5. Освітня програма першого рівня вищої «Початкова освіта» за освітньо-професійним ступенем «молодший спеціаліст» КЗ «Балтський педагогічний фаховий коледж». URL: https://wixlabs-pdfdev.appspot.com/assets/pdfjs/web/viewer. 
6. Професійний стандарт за професіями «Вчитель початкових класів закладу загальної середньої освіти», «Вчитель закладу загальної середньої освіти», «Вчитель 3 початкової освіти (з дипломом молодшого спеціаліста)». Наказ Міністерства розвитку економіки, торгівлі та сільського господарства України. 23.12.2020. № 2736. URL: https://rada.info/upload/users_files/41868892/07679bad4b9af36be541 48ac42826c1b.pdf.

DOI https://doi.org/10.30525/978-9934-26-173-2-36

\title{
ЦІННІСНО-ОРІЕНТОВАНИЙ КОНТЕКСТ СУЧАСНОЇ ОСВІТИ В УКРАЇНI
}

\author{
Яроменко В. I. \\ методист НМЛ громадянської, історичної та мистецької освіти \\ КЗВО «Одеська академія неперервної освіти Одеської обласної ради» \\ м. Одеса, Україна
}

Світ XXI століття - це світ становлення глобальної господарської системи, світ, у якому знання й інтелект стають новою формою власності. Сучасні глобалізаційні процеси суттєво впливають і на зміну традиційної системи цінностей національної культури та моралі, і на духовний стан особистості, а саме на їі духовні цінності та світоглядні орієнтири. Перевага матеріальних цінностей над духовними призводить до того, що духовна сутність людини витісняється прагматизмом та примітивним мисленням, духовно - культурний розвиток особистості порушується. Саме духовно-моральна деградація, як основна проблема, стала причиною теперішніх соціально-економічних, політичних, культурних потрясінь, в яких перебуває українське суспільство. Під впливом цих факторів в Україні «відбувається нова аксіологічна революція, пов'язана 3 переглядом основних цінностей життя, 3 формуванням нового розуміння світу, людини, місця людини у світі під впливом ряду глобальних факторів, які призводять до загострення соціальної конфронтації, нестримної господарсько- економічної гонки, яка не зважає на обмеженість ресурсів планети і можливостями для виживання» [3, с. 4].

Мета дослідження - висвітлити важливість застосування ціннісноорієнтованого підходу в навчально-виховному процесі сучасної української школи. 